\title{
INNOVATION-DRIVEN GROWTH MODEL IN THE PRESENT CONTEXT OF BUSINESS PERFORMANCE
}

\author{
Tetiana Aloshyna', Dmytro Kozenkov² \\ National Metallurgical Academy of Ukraine, Ukraine
}

\begin{abstract}
Over the last decade, domestic enterprises have faced serious problems in the sphere of innovative development. Government's reluctance to finance innovations has become the major obstacle leading to temporary freezing of innovation activity of enterprises. The study aims at investigating the theoretical foundation of innovative modelling of entrepreneurship and elaborating business development model of modern industrial enterprises, taking into account innovation components and the current state of the country's economy. The theoretical and methodological basis of the research is the conceptual provisions and scientific developments of experts in innovative development and issues relating to the management of innovation processes, published in monographs, periodicals, proceedings of scientific and practical conferences on the problem. In spite of the significant contribution of domestic scholars in research and elaboration of the theoretical background of the country's innovative development, there are a number of aspects regarding the innovations in performance modelling of industrial enterprises, which remain unclear. Results. At the present stage of development, industrial enterprises are bound to seek internal financial resources for innovative development or carry out modernization involving both domestic and foreign investments. In addition, managers of industrial enterprises have realized that innovation activity is the key to the company's successful performance in competitive business environment. Although a significant part of domestic investment has been forwarded to innovative business development, there is a problem with the integral planning of innovative activity. Conclusions and directions for further researches. The authors have developed and proposed the basic model of innovative development of Ukrainian industrial enterprises. The model is based on the above-mentioned models of innovative development taking into account specific characteristics and factors in business model elaboration. This model envisages the development of innovation-oriented enterprise consistent with the context of economic performance. The results of the research can be used for modelling and comprehensive assessment of the model implementation in the enterprises in Dnipro region.
\end{abstract}

Key words: innovations, innovation-driven growth model, innovation process, scientific and technical progress, intensification of innovation activities, characteristics and stages of innovative development model.

JEL Classification: O310, C510, O300, O320, O330

\section{Introduction}

Historically, science, technology, and innovation have always been key factors in societal development. Highly developed countries have intensified and accelerated innovation activity over the past decades. Currently, the innovation trend is becoming increasingly widespread, which provides for competitive advantages to business entities, fosters their market positions and, therefore, it favours economic upturn of the countries, which boosts the development of domestic innovation entrepreneurship.
Unfortunately, Ukraine lacks for environment support of innovation-based economic development these days. The national economy still demonstrates a high level of power consumption and non-competitiveness. The latest research into national business performance has shown that Ukrainian companies have a complex of problems related to elaboration and implementation of innovative development strategies, particularly, as regards uncertainty of performance outcomes. That is why the subject of the research is still of high relevance.

\footnotetext{
Corresponding author:

${ }^{1}$ Department of Management, National Metallurgical Academy of Ukraine.

E-mail: tatiana.aloshyna@gmail.com

${ }^{2}$ Department of Management, National Metallurgical Academy of Ukraine.

E-mail:13managua@gmail.com
} 


\section{Analysis of recent research and publications}

The theoretical framework of innovative development and issues concerning the management of innovation processes have been presented in the papers by such prominent researchers as: Afuah A., Obłój K., Hamel G., Adamenko O.A., Andronnikova N.G., Barkalov S.A., Geets V.M., Danilishyn B., Dzhedzhula V.V., Epifanova I.Yu., Tsvik O.G., Zakharchin G.M., Illyashenko S.M., Kolotyuk O.I., Rogoza M.E., Petukhova O.M., Fedorenko V.G., Huchek M., and others.

In spite of the significant contribution of domestic scholars into research and elaboration of the theoretical background of the country's innovative development, there are a number of aspects regarding innovations in industrial performance modelling, which remain unclear.

\section{Goals and objectives of the study}

The aims of the study are to investigate the theoretical foundation of innovative entrepreneurship modelling and to elaborate a business development model of modern industrial enterprises involving innovation components and taking into account the current state of the country's economy. For this purpose, the study focusses on defining the "model of innovative development", describing a methodology for innovative development modelling, as well as presenting the basic model of innovative development of Ukrainian industrial enterprises.

\section{Analysis of theoretical approaches to modelling innovative development}

The main constituents of the model of innovative development are such economic categories as "model", "innovations", "development model", and "business model of an enterprise". Let's consider some of the mentioned categories in details.

In general terms, the model is a representation of an object, system or concept in the form, which may differ from the actual configuration. Model is a source of information about the object. It helps to interpret, understand or improve the object. Models are seen as copies of an object, regardless of the fact that they can be made of different material and within a different scale or display certain characteristics of the object in an abstract form.

In the context of the research, the model is a detailed profile with the outlined system and logical structure, built on innovation basis (Andronnikova, Barkalov, Burkov, Kotenko, 2001). Such a model consists of interdependent qualitative and quantitative indicators that characterize different economic phenomena. There have to be defined sources and regulation mechanisms, as well as incentive and efficiency of the innovationbased character of a dynamic enterprise.
Any model, concept or scheme should be based on general cornerstone principles such as:

- integrity (complexity);

- cause-and-effect relationship (interrelation, convergence, coexistence of the old and the new);

- synergy;

- emergence (derivation of the tree of objectives for the entire system and its components);

- structuredness;

- adaptability (mobility);

- alternativeness (interchanging of ground-breaking ideas, options);

- consistency;

- non-additivity (synthesis of the old, the contemporary, and the new) (Zakharchyn, 2008).

In its turn, innovation is a transformation of potential scientific-and-technological advance into the practical realm, embodied in new products and technologies.

Contemporary theoretical literature in the field of economics provides diverse definitions of innovations depending on the subject and object of the research. Some scholars define innovation as a process. Particularly, according to V. Fedorenko (Fedorenko, 2003), innovation is a process aimed at the creation, production, development, and qualitative improvement of new products, technologies, and organizational forms.

M. Khuchek considers innovations as changes. He supposes that innovation is a change in engineering and technologies, organization, ecology, economy, and social life of an enterprise (Khuchek, 2002).

In accordance with the 1st Article of the Ukrainian Law "On Innovation Activity", innovation is a newly created (applied) and (or) improved competitive technology, a product or a service, as well as an organizational and technical solution of industrial, administrative, commercial or another kind of nature, which significantly improves the structure and the quality of production and (or) of social sphere.

A list of innovation objects was stated in the 4th Article of the above-mentioned law. Objects of innovation include:

- innovative programs and projects;

- new knowledge and intellectual products;

- business equipment and processes;

- the infrastructure of manufacturing and enterprise;

- organizational and technical solutions of industrial, administrative, commercial or another kind of nature, which significantly improve the structure and quality of production and (or) social services;

- raw materials, mining and processing facilities;

- marketable output;

- foundation mechanism of a consumer market and marketable output distribution and sales.

The development model is the next economic category, which has a morphogenetic nature of the examined notion. According to the authors, development model 
is the main projection of overall economic processes of a company, proposed to management for key goals achievement.

Creation of development model is hardly possible without the elaboration of business-model of an enterprise on the whole.

K. Obłój defines a business model as a general conception of the company operation. In the author's opinion, a business model is a combination of a strategic conception of a company and a technology of its practical realization, considered as the elaboration of a value chain securing effective operation and regenerating its resources and skills efficiently (Obłój, 2014).

A. Afuah gives the following definition of a business model (Afuah, 2014): "A business model is a set of company's activities, its performance techniques including the stipulation of required time, aimed at creating superior customer value (low-cost or differentiated products) and securing position for value take-over."

G. Hamel presented an interesting definition of business model in terms of innovativeness (Hamel, 2007). He interpreted business-model as a foundation of innovative business conception. According to Hamel, implementation of new business models, especially in highly innovative economy sectors, undermines old business approaches to a greater degree rather than the introduction of new technologies does.

The innovative conception of business operations has to be built on the basis of drastic innovations, which break new ground opportunities in the market.

G. Hamel offers a model structure with four major elements including:

- basic strategy;

- strategic facilities;

- communication and relationships with clients;

- network costs.

Summarizing above-mentioned definitions, the authors have proposed the following definition of innovative development model, which is an expression of priorities, directions, structures, incentives, strategies, and mechanisms that shape the innovation policy of the enterprise. It is the basis of business model elaboration, grounded on innovations and underlying processes of the enterprise.

\section{Methodology for forming the innovative development model}

Elaboration of the innovative development model is based on research and assessment of various options of innovative solutions, which meet the company's business image and objectives of its development.

It is necessary to say that innovation activity is a dynamic system that requires periodic adjustments taking into account possible changes in external conditions and new opportunities for the company's growth (Pyetukhova, Silakova, 2011). Stages of elaboration of the innovative development model of enterprises are presented in Fig. 1.

Coordination of innovative strategy of the enterprise with its general business strategy (which aims at solving strategic tasks) is a specific characteristic to be taken into account while elaborating an innovative model.

Strategic tasks directly influence optimization of company's structure and define its harmonized paramount targets. The effectiveness of these objectives depends on the characteristics of the innovative model, which plays an important role in the consistent and coherent performance of an industrial enterprise.

Thus, in the present conditions of economic development, it is possible to use several types of innovative development. This possibility is stipulated by a group of factors (Fedorenko, 2003):

- geographical location of production facilities;

- market (trade area) for final products;

- nature of the response to needs and conditions of social progress;

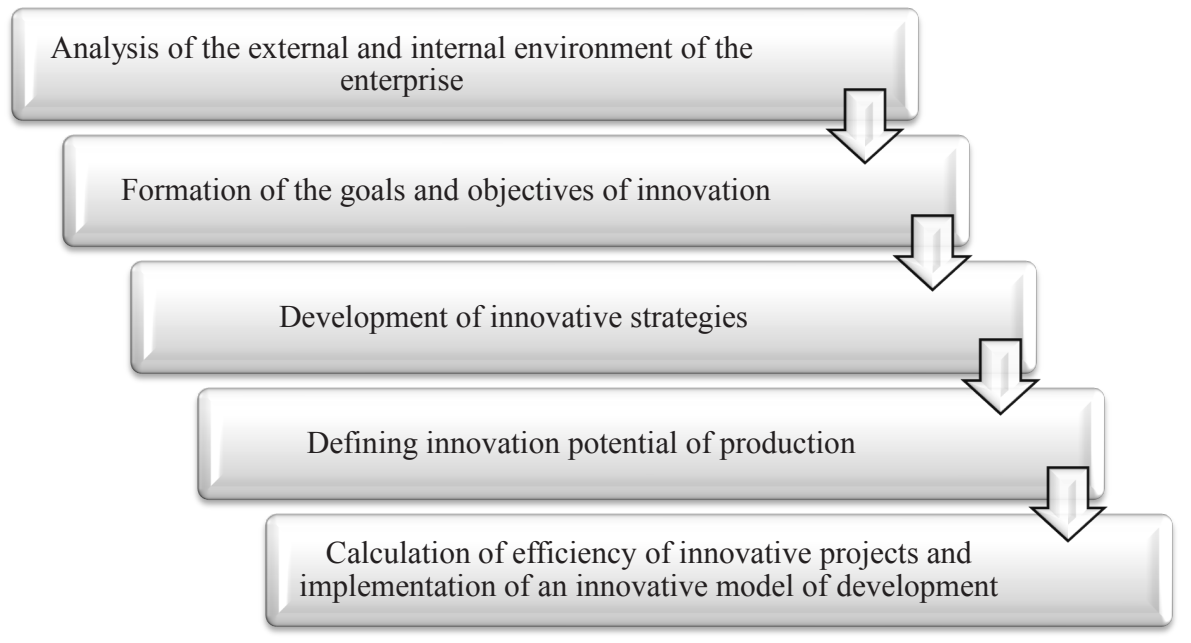

Fig. 1. Stages of the creation of innovative development model of the enterprise 
- potential risks and challenges for the company;

- external characteristics of the industry;

- specific nature of various innovative models.

It should be noted that the model has to be designed with consideration of all above-mentioned factors and priorities of economic development of the company.

There are various models of innovative development, described in the economic literature. Such models are generalized and explained in Table 1.

Table 1

Characteristics of models of the innovative development of the company

\begin{tabular}{|c|c|c|}
\hline № & $\begin{array}{l}\text { Name of the } \\
\text { model }\end{array}$ & The main characteristics of the model \\
\hline 1 & $\begin{array}{c}\text { Model of State } \\
\text { support }\end{array}$ & $\begin{array}{l}\text { - Financing from the state budget; } \\
\text { - Guaranteed food security and alignment } \\
\text { of scientific and technical potential }\end{array}$ \\
\hline 2 & $\begin{array}{l}\text { Local } \\
\text { innovation } \\
\text { environment }\end{array}$ & $\begin{array}{l}\text { - Accumulation of industrial, scientific, } \\
\text { and financial capacity, combined } \\
\text { joint innovation process of enterprise } \\
\text { development; } \\
\text { - Creation of innovative technologies, } \\
\text { products, and logistics }\end{array}$ \\
\hline 3 & $\begin{array}{l}\text { Intra-industry } \\
\text { clusters }\end{array}$ & $\begin{array}{l}\text { - Unification of research and development } \\
\text { in a single innovation chain; } \\
\text { - Concentration on solving business } \\
\text { problems with the use of business } \\
\text { logistics and financial resources }\end{array}$ \\
\hline 4 & $\begin{array}{l}\text { Intra scientific } \\
\text { and technical } \\
\text { complexes }\end{array}$ & $\begin{array}{l}\text { - Establishing cooperation with other } \\
\text { innovation actors; } \\
\text { - Creating innovative systems with the } \\
\text { implementation of all factors that impact } \\
\text { on industrial activity; } \\
\text { - Transfer of technology and quality of } \\
\text { scientific and technological capacity with } \\
\text { minimal resources; }\end{array}$ \\
\hline 5 & Mixed & $\begin{array}{l}\text { - A combination of elements of other } \\
\text { models; } \\
\text { - Serving the interests of industrial } \\
\text { enterprises. }\end{array}$ \\
\hline
\end{tabular}

Undoubtedly, there are no expressively outlined models of innovative development in precise (ultimate) formulations. The most common conception is a model mixed of five others listed above. This model has to be adapted to the needs of each particular company. In each case, a company determines key elements of the model stipulating its production function. Herewith, innovative development model has to be based on innovative changes in all spheres of enterprise performance. Therefore, implementation and extension of innovations by enterprises should take into account:

- Innovation of products;

- Innovation of processes;

- Innovation of personnel;

- Innovation of management activities;

- Innovation of culture.
Transition to an innovative model of a company's performance is determined by the direct influence of environmental factors. Such factors are divided into certain groups.

Different approaches to classification of innovation factors are described in the economic literature. And in our opinion, it is necessary to apply traditional PESTfactors for holistic analysis of the model and research of the following groups of factors:

- political and legal;

- economic and information;

- engineering and technologies;

- organizational;

- socio-cultural.

More detailed description of each group of abovestated factors is presented in Table 2 below.

Table 2

The main factors of innovative development

\begin{tabular}{|c|c|c|}
\hline № & $\begin{array}{c}\text { Factors of innovative } \\
\text { development }\end{array}$ & Influence quantity \\
\hline 1 & Political and legal & $\begin{array}{l}\text { - creation of a legal framework } \\
\text { for the innovative development of } \\
\text { Ukrainian enterprises on the basis of } \\
\text { laws and regulations; }\end{array}$ \\
\hline 2 & $\begin{array}{l}\text { Economic and } \\
\text { information }\end{array}$ & $\begin{array}{l}\text { - acceleration of vertical and } \\
\text { horizontal integration in the } \\
\text { international space; } \\
\text { - influence through the increased } \\
\text { competition in the old markets and } \\
\text { new markets in line with the needs } \\
\text { of society. }\end{array}$ \\
\hline 3 & $\begin{array}{l}\text { Technical and } \\
\text { technological }\end{array}$ & $\begin{array}{l}\text { - creation of new ways to satisfy } \\
\text { needs; } \\
\text { - stimulation of innovative } \\
\text { development by improving the level } \\
\text { of education, knowledge, and level of } \\
\text { scientific development; } \\
\text { - impact on the technical and } \\
\text { technological aspects of innovative } \\
\text { enterprises. }\end{array}$ \\
\hline 4 & $\begin{array}{l}\text { Organizational and } \\
\text { management }\end{array}$ & $\begin{array}{l}\text { - impact on innovation sphere } \\
\text { through institutional governance } \\
\text { and institutional and organizational } \\
\text { changes. }\end{array}$ \\
\hline 5 & Socio-cultural & $\begin{array}{l}\text { - a detachment of socio-cultural } \\
\text { impact of innovation on the } \\
\text { influence of many other factors. }\end{array}$ \\
\hline
\end{tabular}

There are three innovative development models subject to the level of factors and innovation process arrangement in the company:

1. Innovative development based on internal organization, when innovation is elaborated and tested inside the enterprise by its functional units employing planning and monitoring of their interactions within an innovation project of the company.

2. Innovative development based on external organization. Such a model envisages elaboration of 
innovations by means of contracting when bid requests for elaboration and testing are allotted to external agencies.

3. Innovative development based on external organization with the help of venture companies. In this case, a parent company has to establish affiliated venture companies for the innovation project implementation. These affiliated companies underwrite additional funds for new projects realization (Zakharchyn, 2008).

\section{The basic model of innovative development of Ukrainian industrial enterprises}

The authors have developed and proposed a basic model of innovative development of Ukrainian industrial enterprises. Worked-out model is based on the above-stated models of innovative development taking into account specific characteristics and factors of business model elaboration. This model envisages the development of innovation-oriented enterprise consistent with the context of economic performance (Fig. 2).

In the authors' opinion, the basic structural components of innovative development model of an industrial enterprise should be:

- a basic strategy of the company;

- strategic directions of business performance;
- a market of business activities.

The basic strategy of the enterprise should consist of the following elements: objectives; mission; the structure of the company's potential; competitive position of the company; its financial result from the strategy implementation.

The basic strategy has to be oriented to the process of targeted consistent change of the company's standing in accordance with its innovation potential. The latter is an ability to create new opportunities for subsequent business performance by the implementation of new solutions, ideas, and outcomes of innovations.

The above-stated elements of the strategy define strategic directions of the company's development, which play a role of the vector of activities and a guideline for the company's development in the current economic conditions. Strategic directions of business performance and company's strategy itself shall be considered in a close connection with each other because they are mutually conditioned.

Introduction of innovations in all areas of the enterprise activity is a prerequisite for strategic directions' change and strengthening of the company's position in the market.

In accordance with the developed model, strategic directions of the company shall be associated with the expansion of the market by means of permanent research

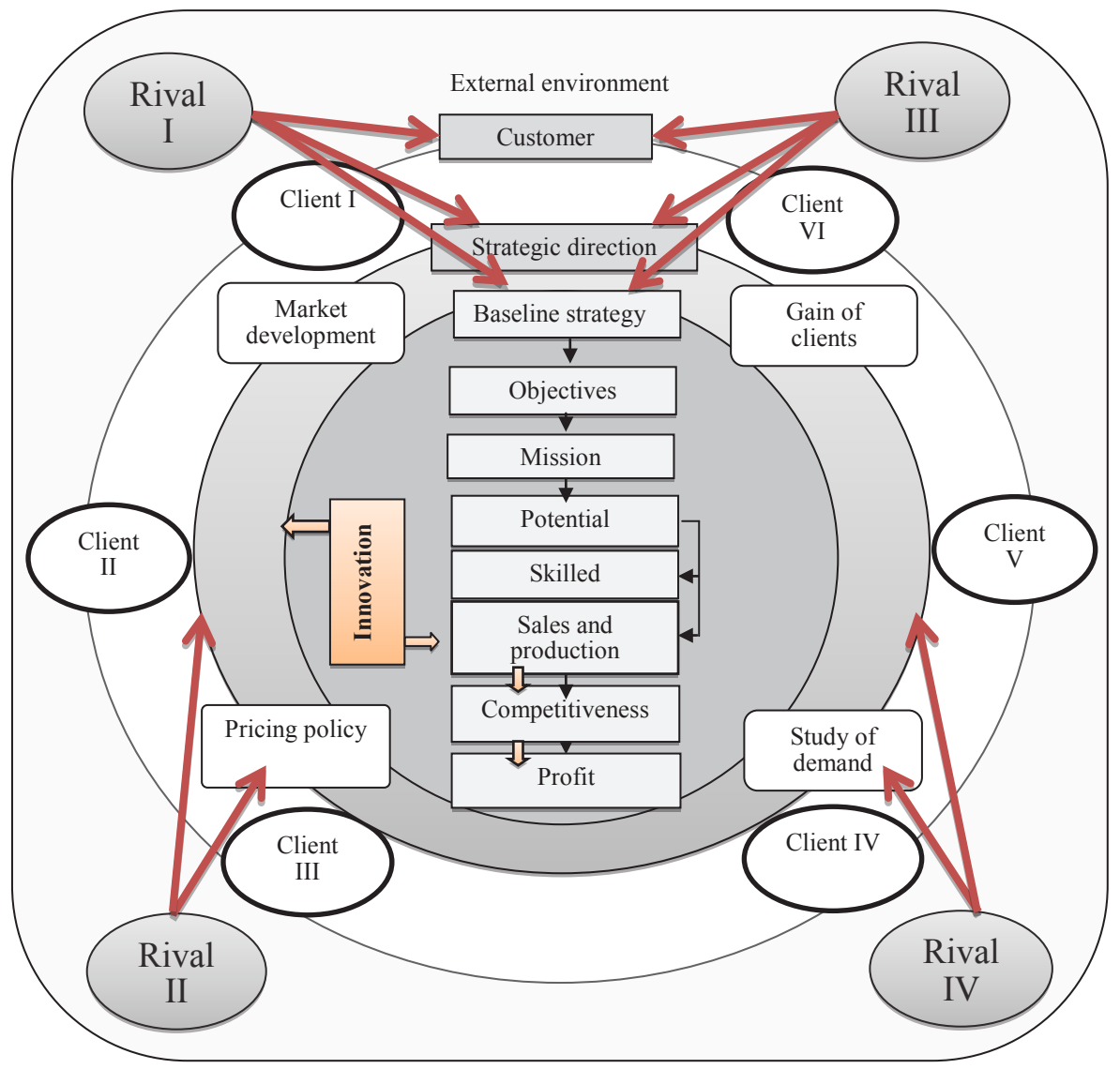

Fig. 2. Basic model of innovative development of industrial enterprises 
of market demand and maintaining of competitive prices providing that quality of products is high.

Market analysis of the company's activities has to be done with its breakdown into structural components and market participants. Under the market structure, we understand the balance of supply and demand for goods and services in the market. Market participants are competitors, suppliers, and customers.

The model, proposed by the authors, stipulates a close relationship between a company and its consumers, on the one hand, and a company and its competitors, on the other, all together operating in the same market. Therefore, market analysis of the needs, opportunities, and activities of both consumers and competitors should be a top-priority task and an activity guideline at all stages of the model functioning along with innovative vectors of industrial enterprises' development.

It should be noted that proposed modelling of the company's innovative policy in modern conditions of economic development involves achievement of relevant goals:

- development of viable industrial complex fostering competitiveness in domestic and foreign markets;

- satisfying consumers' needs in the market for the company's business activities;

- reducing the company's dependence on suppliers;

- increasing capabilities for the market expansion exploiting competitive advantages and implementing innovative components;

- improvement of the company's competitiveness by increasing its workforce capacity, resource and innovative potential.

\section{Conclusions}

Over the last decade, domestic enterprises have faced serious problems in the sphere of innovative development. Government's reluctance to finance innovations has become the major restraint, which has led to the temporary freezing of innovation activity of enterprises.

At the present stage of development, industrial enterprises are bound to rely on internally financing innovative development or carry out modernization involving both domestic and foreign investments. In addition, managers of industrial enterprises have realized that innovation activity is the key to successful performance of the enterprise in the competitive business environment. Although a significant part of domestic investment has been forwarded to innovative business development, there is a problem with the integral planning of innovative activity.

To summarize:

1. There is no common view on the definition of a model of innovative development. The main constituents of the "model of innovative development" are such economic categories as: "model", "innovations", "development model", and "business model of an enterprise". Summing up the above-mentioned definitions, the authors have proposed the definition of innovative development model as an expression of priorities, directions, structures, incentives, strategies, and mechanisms that shape the innovation policy of the enterprise. It is the basis of business model elaboration, grounded on innovations and underlying processes of an enterprise.

2. The authors have laid out the main characteristics, principles, factors, and stages of forming the innovative development model. Thus, the elaboration of the innovative development model is based on several steps, namely, arranging the stages of modelling procedure, coordinating the innovative strategy of an enterprise and its general business strategy, and including all factors in innovative development. Studying theoretical sources made it possible to develop the model of innovative business development described in the paper.

3. The model presented is a visualized concept of involving and implementing innovative components in industrial enterprises' development strategies. The model takes into account the company's market environment and activities of all market participants enabling it to differentiate strategic directions of enterprise development in theoretical and practical terms.

\section{References:}

Adamenko O.A. (2010) Kontseptualni zasady innovatsiynoho rozvytku pidpryiemstv [Conceptual frameworks of innovative development of enterprises]. Naukovi pratsi Natsionalnoho universytetu kharchovykh tekhnolohiy, no. 35, pp. 5-10.

Andronnikova N.G., Barkalov S.A., Burkov V.N., Kotenko A.M. (2001) Modeli i metody optimizacii regionalnyh programm razvitiya [Models and methods of optimization of regional programs of development]. Moscow: IPK RAN, 60. (in Russian).

Afuah A (2014) Bussiness Model Innovation. Concepts, Analysis and Cases. New York : Routledge, p. 376.

Danylyshyn B. \& Chyzhova V. (2004) Naukovo-innovatsiyne zabezpechennya staloho ekonomichnoho rozvytku Ukrayiny. [Scientific and innovation guarantee of sustainable economic development of Ukraine]. Ekonomika Ukrayiny, no. 3, pp. 4-11. Retrieved from: http://www.investplan.com.ua/pdf/4_2017/3.pdf

Dzhedzhula V.V., Epifanova I.Yu., Tsvik O.G. (2017) Innovatsiyna diyalnist yak chinnik konkurentospromozhnosti pidpriemstva. [Innovative activity as a factor of competitiveness of the enterprise]. Investitsii: praktika ta dosvid, no. 4, pp. 5-8. 
Fedorenko V.H. (2003) Innovatsiyna i investytsiyna stratehiya Ukrayiny [Innovation and investment strategy of Ukraine]. Ekonomika ta derzhava, no. 8, pp. 16-27.

Geets V.M. (2015) Baryery na shlyakhu rozvytku promyslovosti na innovatsiyniy osnovi ta mozhlyvosti yikh podolannya. [Barriers to industrial innovative development and opportunities to negotiation]. Ekonomika Ukrayiny, no. 1, pp. 4-25.

Hamel G. (2007) The Future of Management, Boston, Harvard Business Review Press, 288.

Illyashenko S.M. (2010) Stratehichne upravlinnya innovatsiynoyu diyalnistyu pidpryyemstva na zasadakh marketynhu innovatsiy [Strategic innovation management on the marketing innovation basis]. Aktualni problemy ekonomiky, no. 12, pp. 111-119.

Kolotyuk O.I. (2017) Innovatsiyna diyalnist yak skladova konkurentnogo potentsialu pidpriemstva mashinobuduvannya [Innovative activity as a component of the competitive potential of the machine-building enterprise]. Visnik Nats. tekhn. un-tu "KhPI": zb. nauk. pr. Ser.: Ekonomichni nauki., no. 24 (1246), pp. 15-18.

Khuchek M.V. (2002). Innovatsii na pidpriemstvakh ta ikh vprovadzhennya [Innovations at the enterprises and their introduction]. Moscow: Luch, 258 (in Russian)

Obłój K. (2014) Strategia organizacji. PWE Polskie Wydawnictwo Ekonomiczne, p. 416.

Pyetukhova O.M., Silakova H.V. (2011) Rozvytok modeley innovatsiynoho protsesu [Development of models of the innovation process]. The journal of Zhytomyr state technological university, no. 2 (56), pp. 96-103.

Rohoza M.Ye., Verhal K.Yu (2008) Teoretychni aspekty formuvannya modeli stratehichnoho innovatsiynoho rozvytku pidpryyemstva [The theoretical aspects of forming the strategic models of innovative company]. Ekonomichnyy visnyk Natsionalnoho hirnychoho universytetu, no. 3, p. 91-96.

Zakharchyn H.M. (2008) Innovatsiyna kultura v innovatsiyniy systemi pidpryyemstva [Innovation culture in the innovation system of enterprise]. Kultura narodov Prychernomorya, no.125, pp.19-21.

Zakon Ukrayiny (2002) «Pro innovatsiynu diyalnist» from 04.07.2002 № 40-IV Retrieved from: http://zakon0.rada.gov.ua/laws/show/40-15 